\title{
EFEK HEPATOPROTEKTOR EKSTRAK ETANOL RIMPANG DRINGO (Acorus calamus L.) TERHADAP PENINGKATAN KADAR SGPT TIKUS PUTIH (Rattus norvegicus)
}

\author{
Hendra Herman, Sitti Amirah, Triani Putri Ayu \\ Fakultas Farmasi Universitas Muslim Indonesia. Makassar \\ Email: hendra.herman@umi.ac.id
}

\begin{abstract}
Hepatoprotector is a liver protected-agent of hepatotoxic. This research was aimed to determine the hepatoprotector effect of ethanol extract of dringo rhizome (Acorus calamus L.) and most effective dose as a hepatoprotector. The study using 20 male rats divided into 5 groups. Group I was given the $\mathrm{Na}-\mathrm{CMC} 1 \%$, group II was given a herbal supplement, and group III, IV, and $V$ were given ethanol extract of the rhizome dringo (Acorus calamus L.) with a dose of $50 \mathrm{mg} / 100 \mathrm{mg}, \mathrm{kgBB} / \mathrm{kgBB}$, and $200 \mathrm{mg} / \mathrm{kgBB}$ orally for 7 days. At $5^{\text {th }}$ day interval 2 hours after administering the test preparations were given a single dose of $2 \mathrm{~g}$ of paracetamol $/ \mathrm{kgBB}$ in all groups except the Group I. Measurement of levels of SGPT is done before and after the treatment the animal test. From the results of a statistical analysis of Kruskal-Wallis' test followed by Man-Whitney's test that dringo Rhizome (Acorus calamus L.) ethanol extracts has the effect of a hepatoprotector in rats. Extract $50 \mathrm{mg} / \mathrm{kgBB}$ dose has the same effect as statistically with herbal supplements' group (>p 0.05).
\end{abstract}

Key words : Hepatoprotector, dringo rhizome, Acorus calamus L.

\section{PENDAHULUAN}

Hati adalah organ terbesar dan terpenting dalam tubuh yang terletak di rongga perut sebelah kanan tepatnya di bawah diafragma. Hati memiliki fungsi sebagai tempat metabolisme, detoksifikasi, pembentukan dan ekskresi empedu. ${ }^{1,2}$ Hati dapat mengalami berbagai gangguan yang menyebabkan fungsi hati tidak bekerja dengan normal. Oleh karena itu diperlukan perlindungan pada organ hati.

Salah satu parameter yang dapat digunakan untuk menilai fungsi hati yaitu SGPT (Serum Glutamat Piruvat Transaminase). Menurut Chopra 2001, SGPT merupakan enzim yang spesifik untuk kelainan hati dimana akan terjadi peningkatan kadar dalam darah. ${ }^{3}$ Gangguan organ hati dapat disebabkan oleh obat, senyawa 
Efek hepatoprotektor ekstrak etanol rimpang dringo (Acorus calamus L.) terhadap peningkatan kadar SGPT tikus putih (Rattus norvegicus)

kimia, radikal bebas dan virus. ${ }^{2,4}$

Menurut data RISKESDAS (Riset

Kesehatan Dasar) tahun 2010, menyatakan bahwa terdapat sekitar 2000 kasus kerusakan organ hati yang terjadi setiap tahun di mana 39\% disebabkan oleh toksisitas dari parasetamol. $^{5}$

Besarnya potensi kerusakan hati dapat dicegah dengan pemberian senyawa yang bertindak sebagai zat pelindung hati (hepatoprotektor). Senyawa hepatoprotektor banyak diperoleh dari tanaman.

Salah satu tumbuhan yang secara empiris digunakan sebagai tanaman obat yakni rimpang dringo (Acorus calamus L.). Tumbuhan ini memiliki kandungan kimia seperti minyak atsiri, tanin, sesquiterpen, terpenoid, flavonoid dan alkaloid. ${ }^{6}$ Dimana menurut Muthulakshmi et al 2015 bahwa rimpang dringo (Acorus calamus L.) memiliki aktivitas sebagai antioksidan. ${ }^{7}$ Menurut Mahboob et al 2014, melaporkan bahwa potensi hepatoprotektor dari ekstrak etanol rimpang dringo yang diinduksi karbontetra-klorida $\left(\mathrm{CCl}_{4}\right)$ mengalami penurunan nilai SGPT yang signifikan. Oleh karena itu, rimpang dringo (Acorus calamus L.) memiliki potensi sebagai hepatoprotektor. ${ }^{8}$ Berdasarkan uraian diatas, maka dilakukan penelitian tentang ekstrak etanol rimpang dringo (Acorus calamus L.) sebagai hepatoprotektor yang diinduksi parasetamol terhadap peningkatan kadar SGPT pada tikus putih (Rattus norvegicus).

\section{METODE PENELITIAN}

Penelitian ini merupakan penelitian eksperimental laboratorium dengan parameter SGPT. Dimana penelitian ini menggunakan 20 ekor tikus putih yang dibagi dalam 5 kelompok perlakuan yaitu kelompok kontrol normal (Na.CMC 1\%) kelompok kontrol positif (suplemen herbal) dan 3 kelompok uji ekstrak dengan dosis I (50 $\mathrm{mg} / \mathrm{kgBB}$ ), dosis II (100 mg/kgBB), serta dosis III (200 mg/kgBB), yang diberikan sekali sehari selama 7 hari secara oral. Pada hari ke 5 selang 2 jam setelah pemberian sediaan uji diberikan parasetamol dosis $2 \mathrm{~g} / \mathrm{kgBB}$ kecuali kelompok I. Kemudian pada hari ke 7 selang 2 jam setelah perlakuan semua kelompok dilakukan pengukuran kadar SGPT.

\section{Alat dan bahan yang digunakan}

Alat-alat yang digunakan dalam penelitian ini adalah human analyzer (microlab 300), mikropipet (Huawei), restrainer, sentrifuge (PLC series), tabung, timbangan analitik (OHaus). Bahan-bahan yang digunakan dalam penelitian ini adalah rimpang dringo 
Efek hepatoprotektor ekstrak etanol rimpang dringo (Acorus calamus L.) terhadap peningkatan kadar SGPT tikus putih (Rattus norvegicus)

(Acorus calamus L.), etanol 96\%, parasetamol, suplemen herbal, Na.CMC (Natrium Carboxy Methyl Cellulose) $1 \%$, pereaksi uji ALT/GPT (Elithech).

\section{Prosedur Kerja}

Pembuatan suspensi ekstrak etanol rimpang dringo

Sediaan ekstrak etanol rimpang dringo dosis $50 \mathrm{mg} / \mathrm{kgBB}, 100$ $\mathrm{mg} / \mathrm{kgBB}$, dan 200 mg/kgBB dibuat dengan cara ditimbang ekstrak secara berturut-turut $50 \mathrm{mg}, 100 \mathrm{mg}$, dan 200 mg masing-masing disuspensikan dengan $10 \mathrm{~mL} \mathrm{Na.CMC} 1 \%$.

\section{Pembuatan suspensi parasetamol 2 g/kgBB}

Suspensi parasetamol dengan dosis $2 \mathrm{~g} / \mathrm{kgBB}$ dibuat dengan cara menimbang parasetamol sebanyak 2,396 g kemudian disuspensikan ke dalam Na.CMC sebanyak $10 \mathrm{~mL}$.

\section{Perlakuan terhadap hewan uji}

Tikus putih diadaptasikan terlebih dahulu selama \pm 14 hari dan dipuasakan terlebih dahulu selama 8 jam sebelum perlakuan. Dilakukan pengambilan darah awal untuk pengukuran kadar SGPT yang dibagi dalam 5 kelompok yaitu, Kelompok I diberikan Na.CMC 1\%, kelompok II diberikan Suplemen herbal kelompok III, IV dan V diberikan ekstrak etanol rimpang dringo dengan variasi dosis 50
mg/kgBB, 100 mg/kgBB, 200 mg/kgBB. Semua kelompok diatas diberi perlakuan selama 7 hari secara oral. Pada hari ke 5 selang 2 jam diberikan parasetamol dosis $2 \mathrm{~g} / \mathrm{kgBB}$ kecuali kelompok I. Pada hari ke 7 selang 2 jam dilakukan pengukuran kadar SGPT akhir.

\section{Pengambilan Sampel Darah Hewan} Uji

Pengambilan sampel darah dilakukan melalui vena lateralis pada ekor. Sampel darah diambil sebanyak 1 $\mathrm{mL}$ kemudian darah ditampung dalam tabung Eppendorf. Setelah itu, sampel darah disentrifuge dengan kecepatan 10000 rpm selama 10 menit kemudian diambil serumnya.

\section{Pengukuran kadar SGPT darah Hewan Uji (Elitech procedure)}

Pengukuran kadar SGPT dengan cara dipipet sebanyak $240 \mu \mathrm{l}$ reagen I dimasukkan sampel serum sebanyak $30 \mu$ dan dihomogenkan selama 25 detik kemudian didiamkan. Pada waktu 4 menit 42 detik ditambahkan dengan reagen II sebanyak $60 \mu \mathrm{l}$ dan dihomogenkan, pada waktu 5 menit 23 detik diukur kadar SGPT pada alat Human Analyzer (microlab 300).

\section{Analisis Data}

Penelitian yang dilakukan adalah penelitian eksperimental 
Efek hepatoprotektor ekstrak etanol rimpang dringo (Acorus calamus L.) terhadap peningkatan kadar SGPT tikus putih (Rattus norvegicus)

laboratorium dan bersifat kuantitatif

non-parametrik yaitu uji Kruskal-Wallis dengan diujikan pada hewan uji. dan dilanjutkan dengan uji MannAnalisis data menggunakan metode uji Whitney.

\section{HASIL PENELITIAN}

Tabel 1. Data rata-rata hasil pengukuran kadar SGPT tikus putih (Rattus norvegicus) awal dan akhir perlakuan sediaan uji

\begin{tabular}{cccc}
\hline \multirow{2}{*}{ No } & Kelompok Perlakuan & \multicolumn{2}{c}{ Hasil Pengukuran Kadar SGPT(U/L) } \\
\cline { 3 - 4 } & & Awal \pm SD & Akhir \pm SD \\
\hline 1 & Kontrol normal & $44,07 \pm 2,31$ & $45,00 \pm 1,47$ \\
2 & Kontrol positif & $48,67 \pm 2,93$ & $29,03 \pm 9,58$ \\
3 & EERD 50 mg/kgBB & $49,13 \pm 3,46$ & $37,50 \pm 11,73$ \\
4 & EERD 100 mg/kgBB & $49,93 \pm 0,32$ & $44,07 \pm 2,64$ \\
5 & EERD 200 mg/kgBB & $47,30 \pm 5,02$ & $46,83 \pm 5,23$ \\
\hline
\end{tabular}

Keterangan: Data ditunjukkan dalam rata-rata \pm SD dengan $n=3$. EERD (Ekstrak etanol rimpang dringo (Acorus calamus L.)

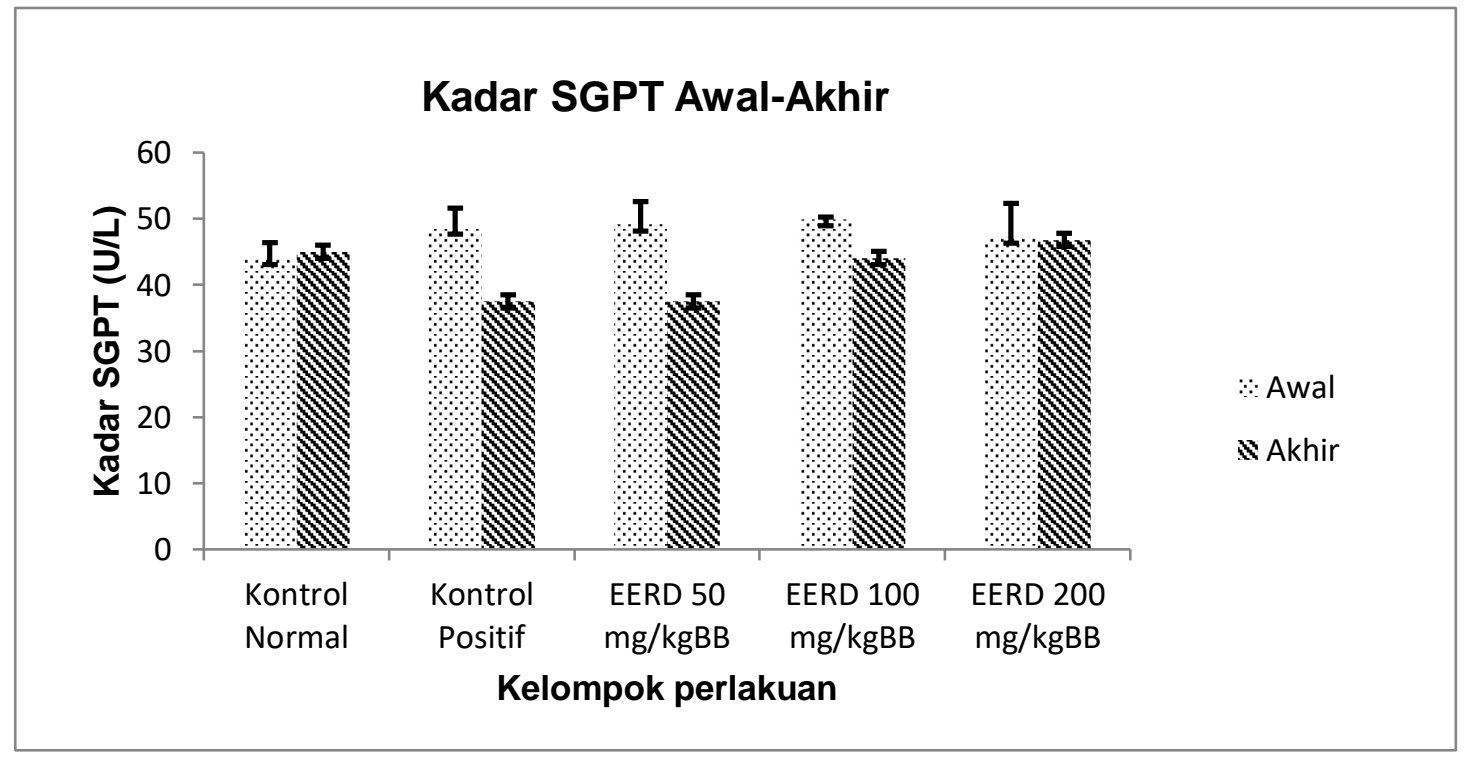

Gambar 1. Diagram rata-rata hasil pengukuran kadar SGPT sebelum dan sesudah perlakuan sediaan uji 
Efek hepatoprotektor ekstrak etanol rimpang dringo (Acorus calamus L.) terhadap peningkatan kadar SGPT tikus putih (Rattus norvegicus)

Tabel 2. Analisis Statistik Uji Kruskal-Wallis

\begin{tabular}{ccc}
\hline No & Kelompok perlakuan & Nilai Signifikansi $(\mathbf{p}<\mathbf{0 , 0 5})$ \\
\hline 1 & Kontrol Normal & \\
2 & Kontrol Positif & 0,033 \\
3 & EERD $50 \mathrm{mg} / \mathrm{kgBB}$ & \\
4 & EERD $100 \mathrm{mg} / \mathrm{kgBB}$ & \\
5 & EERD $200 \mathrm{mg} / \mathrm{kgBB}$ & \\
\hline
\end{tabular}

Tabel 3. Analisis Statistik Uji Mann-Whitney Terhadap Kadar SGPT

\begin{tabular}{ccc}
\hline Kelompok Perlakuan & $\mathbf{P}$ & Keterangan \\
\hline I-II & 0,049 & berbeda nyata \\
I-III & 0,049 & berbeda nyata \\
I-IV & 0,827 & Tidak berbeda nyata \\
I-V & 0,513 & Tidak berbeda nyata \\
II-III & 0,275 & Tidak berbeda nyata \\
II-IV & 0,049 & berbeda nyata \\
II-V & 0,049 & berbeda nyata \\
III-IV & 0,049 & berbeda nyata \\
III-V & 0,049 & berbeda nyata \\
IV-V & 0,513 & Tidak berbeda nyata
\end{tabular}

Keterangan :

I: : Na.CMC $1 \%$

II : Suplemen Herbal + Parasetamol $2 \mathrm{~g} / \mathrm{kgBB}$

III : EERD $50 \mathrm{mg} / \mathrm{kgBB}+$ Parasetamol $2 \mathrm{~g} / \mathrm{kgBB}$

IV : EERD $100 \mathrm{mg} / \mathrm{kgBB}+$ Parasetamol $2 \mathrm{~g} / \mathrm{kgBB}$

$\mathrm{V} \quad$ : EERD $200 \mathrm{mg} / \mathrm{kgBB}+$ Parasetamol $2 \mathrm{~g} / \mathrm{kgBB}$

\section{PEMBAHASAN}

Hepatoprotektor merupakan senyawa yang dapat melindungi organ hati terhadap hepatotoksisitas. Dimana penelitian ini bertujuan untuk menentukan efek hepatoprotektor ekstrak etanol rimpang dringo (Acorus calamus L.) pada tikus putih (Rattus norvegicus) berdasarkan kadar SGPT yang diinduksi dengan parasetamol.
Penelitian ini dilakukan dari pengukuran kadar SGPT awal pada hewan uji tikus putih (Rattus norvegicus) kemudian diberikan perlakuan selama 7 hari. Pada hari ke 5 selang 2 jam setelah pemberian sediaan uji diberikan parasetamol dosis tunggal $2 \mathrm{~g} / \mathrm{kgBB}$ kecuali kelompok kontrol normal. Pada hari ke 7 selang 2 jam setelah pemberian sediaan uji 
Efek hepatoprotektor ekstrak etanol rimpang dringo (Acorus calamus L.) terhadap peningkatan kadar SGPT tikus putih (Rattus norvegicus)

dilakukan pengambilan darah untuk mengukur kadar SGPT akhir.

Gambar 2 menunjukkan bahwa kelompok kontrol normal mengalami sedikit peningkatan rata-rata kadar SGPT dibandingkan semua kelompok perlakuan. Kelompok kontrol positif memiliki nilai rata-rata kadar SGPT yang paling rendah dibandingkan semua kelompok uji ekstrak. Adapun kelompok uji ekstrak yang memiliki nilai rata-rata kadar SGPT paling rendah yaitu EERD dengan dosis $50 \mathrm{mg} / \mathrm{kgBB}$.

Data hasil penelitian dianalisis secara statistik untuk melihat kemampuan ekstrak etanol rimpang dringo sebagai hepatoprotektor. Hasil uji normalitas menunjukkan bahwa data penelitian tidak terdistribusi normal sehingga dipilih metode uji non parametrik yaitu uji Kruskal-Wallis untuk melihat perbedaan kadar SGPT pada tiap kelompok perlakuan. Data persen penurunan (\%) kadar SGPT dianalisis statistik menggunakan uji Kruskal-Wallis yang hasilnya dapat dilihat pada tabel 2 .

Hasil uji Kruskal-Wallis menunjukkan ada perbedaan antara kelompok perlakuan. Untuk mengetahui perbedaan antara kelompok perlakuan, maka dilakukan analisis lanjutan dengan menggunakan uji Mann-Whitney yang hasilnya dapat dilihat pada tabel 3 .

Hasil uji Mann-Whitney menunjukkan bahwa kelompok kontrol normal memiliki efek yang tidak sama dengan kelompok kontrol positif. Kelompok kontrol positif memiliki perlindungan terhadap kerusakan hati yang lebih besar dibandingkan dengan kelompok kontrol normal. Kelompok kontrol positif memiliki efek yang sama dengan kelompok uji ekstrak dosis 50 $\mathrm{mg} / \mathrm{kgBB}$, hal ini berarti kelompok uji ekstrak $50 \mathrm{mg} / \mathrm{kgBB}$ memiliki kemampuan perlindungan hati yang sama dengan kelompok kontrol positif. Kelompok uji ekstrak dosis 100 $\mathrm{mg} / \mathrm{kgBB}$ dan $200 \mathrm{mg} / \mathrm{kgBB}$ memiliki efek yang sama dengan kelompok kontrol normal, hal ini berarti kelompok uji ekstrak 100 mg/kgBB dan 200 $\mathrm{mg} / \mathrm{kgBB}$ memiliki kemampuan perlindungan hati yang sama dengan kelompok kontrol normal.

Berdasarkan hasil analisis data menunjukkan ekstrak etanol rimpang dringo dosis $50 \mathrm{mg} / \mathrm{kgBB}, 100$ $\mathrm{mg} / \mathrm{kgBB}$, dan $200 \mathrm{mg} / \mathrm{kgBB}$ memiliki efek hepatoprotektor. Dosis yang paling efektif sebagai hepatoprotektor yaitu dosis $50 \mathrm{mg} / \mathrm{kgBB}$. Efek hepatoprotektor yang dimiliki oleh ekstrak etanol rimpang dringo (Acorus calamus L.) diduga karena adanya 
Efek hepatoprotektor ekstrak etanol rimpang dringo (Acorus calamus L.) terhadap peningkatan kadar SGPT tikus putih (Rattus norvegicus)

kandungan kimia flavonoid.

Kandungan flavonoid dapat meredam dan menekan pembentukan radikal bebas atau ROS dengan cara menghambat enzim yang terlibat dalam pembentukan ROS, serta menghambat pengkhelatan ion logam yang terlibat dalam produksi radikal bebas. ${ }^{9}$

\section{KESIMPULAN}

Hasil penelitian yang telah dilakukan dapat disimpulkan sebagai berikut bahwa ekstrak etanol rimpang dringo (Acorus calamus L.) memiliki efek hepatoprotektor pada tikus putih (Rattus norvegicus). Dosis ekstrak etanol rimpang dringo (Acorus calamus L.) yang efektif sebagai hepatoprotektor yaitu dosis ekstrak 50 $\mathrm{mg} / \mathrm{kgBB}$.

\section{DAFTAR PUSTAKA}

1. Sherwood L. Fisiologi manusia edisi 7. Jakarta: EGC, 2014

2. Price SA, Wilson RM. Patofisiologi Konsep Klinis Proses-Proses Penyakit Edisi 6 Volume 1. Jakarta: Penerbit Buku Kedokteran EGC, 2005.
3. Chopra S. The Liver Book: A Comprehensive Guide to Diagnosis, Treatment and Recovery. New York: Pocket Books simon \& Schuster, 2001.

4. Katzung. Farmakologi Dasar \& Klinik Edisi 12. Jakarta : EGC, 2015.

5. Departemen Kesehatan Republik Indonesia. Riset Kesehatan Dasar 2010. Jakarta : DEPKES RI, 2010.

6. Hendrajaya K, Dini K. Skrining Fitokimia Limbah Rimpang Acourus calamus L. yang Telah Terdestilasi Minyak Atsirinya. Jakarta : Fakultas Farmasi, Universitas Pancasila, 2003.

7. Muthulakshmi T, Saleh AM, Kumari NV, Mohana PK, Palanichamy V. Screening of Phytochemicals and in Vitro Antioxidant Activity of Acorus calamus. Int J Drug Dev \& Res.,2015;7(1):44-51.

8. Mahboob SA, Apte Ki, Bhagwat GB. Hepatoprotective Potential of Acorus calamus Against Carbon Tetrachloride Induced Liver Damage in Rats. Int J of PharmTech Res.,2014;6(4):1315-1321.

9. Wahyu, et al. Penapisan Aktivitas Superoksida Dimutase pada berbagai Tanaman. Fakultas MIPA. JKM Vol.5. 2005. 